\begin{abstract}
Iranica
Abstracta Iranica Revue bibliographique pour le domaine irano-aryen

Volume 32-33 | 2013

Comptes rendus des publications de 2009-2010
\end{abstract}

\title{
Shafiq Abouzayd (ed.). Mandaeism
}

\section{Christelle Jullien}

\section{OpenEdition}

\section{Journals}

Édition électronique

URL : http://journals.openedition.org/abstractairanica/40810

DOI : 10.4000/abstractairanica.40810

ISSN : 1961-960X

Éditeur :

CNRS (UMR 7528 Mondes iraniens et indiens), Éditions de l'IFRI

\section{Édition imprimée}

Date de publication : 1 décembre 2013

ISSN : 0240-8910

\section{Référence électronique}

Christelle Jullien, « Shafiq Abouzayd (ed.). Mandaeism », Abstracta Iranica [En ligne], Volume 32-33

2013, document 313, mis en ligne le 01 juillet 2016, consulté le 26 septembre 2020. URL : http:// journals.openedition.org/abstractairanica/40810; DOI : https://doi.org/10.4000/abstractairanica. 40810

Ce document a été généré automatiquement le 26 septembre 2020.

Tous droits réservés 


\title{
Shafiq Abouzayd (ed.). Mandaeism
}

\author{
Christelle Jullien
}

\section{RÉFÉRENCE}

Shafiq Abouzayd (ed.). Mandaeism. ARAM 22, 2010, 611 p.

Ce numéro de la revue Aram est entièrement consacré aux mandéens, groupe de baptistes judéo-chrétiens attestés d'après les plus anciens documents (IVe siècle) en Mésène, au nord du golfe Persique et dans le sud babylonien. Il s'agit de la publication des actes de la XXVI ${ }^{e}$ Conférence internationale organisée par l'A. et la revue Aram tenue à la SOAS de Londres en 2008, comprenant 27 contributions. L'une d'elles (I. Gardner, « Mani's Book of Mysteries. Prolegomena to a New Look at Mani, the 'Baptists' and the Mandaeans») analyse avec finesse la relation supposée de Mani avec le mandéisme naissant à partir d'une nouvelle approche : l'étude du Livre des Mystères manichéen comme lieu de débat entre Mani et les communautés religieuses de son temps, montrant les divergences avec les textes mandéens en dépit de thématiques comparables.

\section{AUTEURS}

\section{CHRISTELLE JULLIEN}

CNRS, Mondes iranien et indien, Paris 